Bangladesh J. Bot. 44(3): 367-372, 2015 (September)

\title{
EFFECTS OF NANO-FERRIC OXIDE ON QUALITY, QUANTITY AND ANTIOXIDANT PROPERTIES OF ESSENTIAL OIL COMPONENTS IN CARUM COPTICUM (L.) LINK
}

\author{
Mohsen KAZEMI ${ }^{1}$ \\ Department of Horticulture, Science and Research Branch, \\ Islamic Azad University, Tehran, Iran
}

Key words: Carum copticum, Nano-ferric oxide, Antioxidant properties

\begin{abstract}
The effect of exogenous application of nano-ferric oxide $(50$ and $100 \mathrm{mg} / \mathrm{l})$ in early flowering stage on components of essential oils (EOs) of Carum copticum (L.) Link was evaluated. EO extracted by hydrodistillation from Iranian $C$. copticum was characterized by means of GC/MS. The nano-ferric oxide application increased limonene, $\gamma$ - terpinene, cis-limonene oxide, thymol, carvacrol and decreased $\alpha$-thujene, $\alpha$-pinene, $\beta$-pinene and p-cymene concentration. The EO was also subjected to evaluation for antioxidant properties. Thymol, $\gamma$-terpinene and carvacrol possessed the highest antioxidant properties among the major components. C. copticum EO exhibited a higher activity in each antioxidant system with a special attention to $\beta$-carotene bleaching test and reducing power. The TLC-bioautography screening and fractionation resulted in the separation of the main antioxidant compounds which were identified as thymol, $\gamma$-terpinene and carvacrol.
\end{abstract}

\section{Introduction}

Nano-technology can provide solution to increasing the value of agricultural products and environmental problems. By using nano-particles and nano-powders, we can produce controlled or delayed releasing fertilizers. They have high reactivity because of more specific surface area, more density of reactivities, or increased reactivity of these areas on the particle surfaces. Antioxidants have been widely used as food additives to provide protection against oxidative degradation of foods by free radicals. Antioxidants are known as molecules capable of inhibiting oxidation process in the body to prevent the formation of free radicals. Recent research is now directed towards finding naturally occurring antioxidants of plant origin. Among these, the antioxidant properties of many aromatic and medicinal plants have shown to be effective in retarding the process of lipid peroxidation in oils and fatty foods and have gained interest of many research groups (Kulisic et al. 2004). The main objectives of the present study were to evaluate the exogenous application of nano-ferric oxide on quality, quantity and antioxidant properties of the essential oil from Carum copticum (L.) Link seeds and to find out which compounds can contribute to the antioxidant activities.

\section{Materials and Methods}

Two separate sets of experiments were conducted in a completely randomized design. In the first set, the effect of exogenous application of nano-ferric oxide $(50$ and $100 \mathrm{mg} / \mathrm{l})$ in early flowering stage on components of EOs of $C$. copticum was evaluated. The second set included investigating the effect of nano-ferric oxide at $100 \mathrm{mg} / \mathrm{l}$ on antioxidant properties.

The plant was identified by Dr. Esmaili, and the voucher specimen was deposited at private herbarium of Dr F. Esmaili (Voucher no. 121). Seeds of $C$. copticum were sown in Jefe pot in experimental greenhouse of Ilam, Iran. Plants at flowering stage (2013 - 2014) were sprayed with

${ }^{1}$ Corresponding author: <kazemimohsen85@gmail.com>. 
distilled water as control and nano ferric oxide at 50 and $100 \mathrm{mg} / \mathrm{l}$ concentration. All solutions were sprayed to the point of run off. The experiment was arranged in CRBD with three replications for each treatment. At seed stage of $C$. copticum plants were harvested and air dried at ambient temperature in the shade.

The $C$. copticum seeds were ground and the resulting powder was subjected to hydrodistillation for $3 \mathrm{hrs}$ in an all glass Clevenger-type apparatus according to the method recommended by the European Pharmacopoeia (1975). The obtained essential oil was dried over anhydrous sodium sulphate and after filtration, stored at $+4^{\circ} \mathrm{C}$ until tested and analysed. GC/MS analyses were executed on a Hewlett-Packard 5973N gas chromatograph equipped with a column (HP-5MS; $30 \mathrm{~m}$ length $\times 0.25 \mathrm{~mm}$ i.d., film thickness $0.25 \mu \mathrm{m}$ ) coupled with a Hewlett-Packard $5973 \mathrm{~N}$ mass spectrometer. The column temperature was programmed at $50^{\circ} \mathrm{C}$ as an initial temperature, holding for $6 \mathrm{~min}$ with $3^{\circ} \mathrm{C}$ increases per minute to $240^{\circ} \mathrm{C}$, followed by a temperature enhancement of $15^{\circ} \mathrm{C}$ per minute up to $300^{\circ} \mathrm{C}$, then holding at the mentioned temperature for 3 min. Injector port temperature was $290^{\circ} \mathrm{C}$ and helium was used as carrier gas at a flow rate 1.5 $\mathrm{ml} / \mathrm{min}$. Ionization voltage of mass spectrometer in the EI-mode was equal to $70 \mathrm{eV}$ and ionization source temperature was $250^{\circ} \mathrm{C}$. Linear retention indices for all components were determined by coinjection of the samples with a solution containing homologous series of $\mathrm{C}_{8}-\mathrm{C}_{22} n$-alkanes and comparing their mass spectra with those of authentic samples or with available library data of the GC/MS system (WILEY 2001 data software) and Adams libraries spectra (2001).

Total phenolic contents in seeds of $C$. copticum were determined by Folin-Ciocalteu method (Jimoh et al. 2007), was expressed as gallic acid equivalents (GAE) (mg/l).

Total flavonoid contents in seeds $C$. copticum were measured as described previously (Piccolella et al. 2008). The total flavonoid content was calculated as rutin equivalents (mg/l).

The efficacy of the essential oils to scavenge 2,2-diphenyl-1-picrylhydrazyl (DPPH) radicals was evaluated by using a spectrophotometric method (Cuendet et al. 1997, Kirby and Schmidt 1997). The basis of bleaching of the bluish-red or purple colour of DPPH solution. Briefly, a $50 \mu 1$ volume of various dilutions of each samples was mixed with $5 \mathrm{ml}$ of $0.004 \%$ methanol solutions of DPPH followed by $30 \mathrm{~min}$ incubation at ambient temperature. Thereafter, the sample absorbance was recorded against control at $517 \mathrm{~nm}$. The percentage inhibition was measured by using following equation. The antioxidants activity of the test samples in concentration providing $50 \%$ inhibition were considered as $\mathrm{IC}_{50}(\mu \mathrm{g} / \mathrm{ml})$.

Inhibition percent $=\mathrm{Abs}_{\text {control }}-\mathrm{Abs}_{\text {sample }} / \mathrm{Abs}_{\text {control }} \times 100$

Butylated hydroxyanisole (BHA) and ascorbic acid were used as positive controls. All experiments were repeated three times and the average results and standard deviations were calculated.

For screening of antioxidant compounds in C. copticum essential oil, the TLC-bioautography method was carried out (Burits and Bucar 2000, Guleria et al. 2012). The diluted oil (1: 20 in methanol) was spotted on silica gel plates (silica gel $60 \mathrm{~F}_{254}$ TLC plates) and developed in $n$-hexane-ethyl acetate $(9: 1)$. Plates were sprayed with methanolic solution of DPPH $(0.2 \%)$. The active constituents were detected as yellow spots on a violet background. Only zones where their color turned from violet to yellow within the first $30 \mathrm{~min}$ (after spraying) were taken as positive results.

For the isolation and identification of the active compounds in the essential oil, TLC was performed using the conditions previously described (Guleria et al. 2012). The regions showing DPPH scavenging activity were scrapped off eluted with chloroform. All resulting constituents were analyzed by GC/MS and also tested for their antioxidant activities. 
The b-CLAMS method of peroxides generation during the oxidation of linoleic acid at elevated temperature (Koleva et al. 2002) was utilized. The antioxidant activity (AA) of the extracts was evaluated in term of $\beta$-carotene using the following formula: AA $(\%)=\left[\left(\mathrm{A}_{0^{-}}\right.\right.$ $\left.\left.A_{1}\right) / A_{0}\right]^{*} 100$ where $A_{0}$ is the absorbance of the control at $0 \mathrm{~min}$, and $A_{1}$ is the absorbance of the sample at $120 \mathrm{~min}$. The results are expressed as $\mathrm{IC}_{50}$ values $(\mu \mathrm{g} / \mathrm{ml})$. All samples were prepared and analyzed in triplicate.

The ability of the extracts to reduce $\mathrm{Fe}^{3+}$ was by the method of Oyaizu (1986). Heres $1 \mathrm{ml}$ of C. copticum essential oil was mixed with $2.5 \mathrm{ml}$ of phosphate buffer $(0.2 \mathrm{M}$, pH 6.6) and $2.5 \mathrm{ml}$ of $1 \% \mathrm{~K}_{3} \mathrm{Fe}(\mathrm{CN})_{6}$. After incubation at $50^{\circ} \mathrm{C}$ for $25 \mathrm{~min}, 2.5 \mathrm{ml}$ of $10 \%$ trichloroacetic acid was added and the mixture was centrifuged at $650 \mathrm{~g}$ for $10 \mathrm{~min}$. Finally, $2.5 \mathrm{ml}$ of the upper layer was mixed with $2.5 \mathrm{ml}$ of distilled water and $0.5 \mathrm{ml}$ of $0.1 \%$ aqueous $\mathrm{FeCl}_{3}$. The absorbance was measured at $700 \mathrm{~nm}$. The mean of absorbance values was plotted against concentration and a linear regression analysis was carried out. Increase in absorbance of the reaction mixture indicated increased reducing power. $\mathrm{EC}_{50}$ value $(\mu \mathrm{g} / \mathrm{ml})$, the effective concentration at which the absorbance was 0.5 for was determined as the reducing power. Ascorbic acid was used as positive control. Inhibition lipid peroxidation was determined by the method of Shirwaikar et al. (2006). Ascorbic acid and trolox was used for comparison.

The results are presented as mean $\pm \mathrm{Sd}$ and statistically analyzed by ANOVA followed by DMRT.

\section{Results and Discussion}

The constituents of the essential oil obtained $C$. copticum treated with nano-ferric oxide are presented in Table 1. Hydrodistillation showed that yield of the seeds of $C$. copticum oil treated with nano-ferric oxide was 3.98\% (v/w). The GC/MS analysis of C. copticum oil revealed 10 compounds representing $97.77 \%$ of the total oil; thymol was the main constituent $(32.78 \%$ ), followed by p-cymene (10.65\%), limonene (5.98\%), $\gamma$-terpinene (28.45\%) and carvacrol (12.00\%) (Table 1). Fifteen components were identified in the untreated plants and eleven components in $100 \mathrm{mg} / \mathrm{l}$ nano-ferric oxide-treated plants (Table 1). The differences were supposed to be the effects of nano-ferric oxide on chemical composition oil of C.copticum. Decrease in the proportion of $\alpha$-thujene, $\alpha$-pinene, $\beta$-pinene, p-cymene, $\beta$-myrcene, $\beta$-phellendrene, $\beta$-fenchyl alcohol, hexadecane and nonadecane have been found according to concentration of nano-ferric oxide. Some compounds such as $\alpha$-thujene, $\beta$-pinene, $\beta$-myrcene, $\beta$-fenchyl alcohol, hexadecane and nonadecane was only detected in control (Table 1). On the other hand, limonene, $\gamma$-terpinene, carvacrol and thymol were increased with nano-ferric oxide-treatment (Table 1). The yield of the C. copticum oil was $1.14 \%$ in control, $2.00 \%(50 \mathrm{mg} / \mathrm{l})$ and $3.98 \%(100 \mathrm{mg} / \mathrm{l})$ in nano ferric oxide significantly increased the yield of EO (Table 1). We harvested plants materials at seeds stage. It may be affected the kind of oils, because it was observed that during the intensive growth period the precursor flow distributes between the cytoplasm (sites of sesquiterpene synthesis) and plastid (sites of monterpen synthesis) while after full development of the cell the majority is utilized in the plastids. Khajeh et al. (2004) showed that hydrodistilled oil of the plant contained eight main compounds, including thymol (49\%), p-cymene (15.7\%), $\gamma$-terpinene (30.8\%) and $\beta$-pinene (2.1\%), but supercritical carbon dioxide extraction (SFE) of the EO revealed only three compounds (thymol, q-cymene and c-terpinene), and the content of each depended on SFE conditions. Kobraee et al. (2011) reported that nano iron foliar application enhanced soybean yield by influencing number of seeds per plant and seed weight. Therefore, iron defficiency in soils could be a limiting factor of yield and extremely decreases crop yield. Lu et al. (2002) have shown that the application of nano fertilizers could increase the nitrate reductase enzyme in 
soybean (Glycine max L.), increase its abilities of absorbing and utilizing water and fertilizer, promote its antioxidant properties, and, in fact, accelerate its germination and growth.

Table 1. Effect of nano-ferric oxide on chemical composition of $C$. copticum essential oil.

\begin{tabular}{|c|c|c|c|c|c|c|}
\hline & \multirow[b]{2}{*}{ Components } & \multicolumn{3}{|c|}{${ }^{\mathrm{a}}$ C. copticum essential oil (\%) } & \multirow{2}{*}{$\begin{array}{l}{ }^{\mathrm{b}} \text { Retention } \\
\text { index }\end{array}$} & \multirow{2}{*}{$\begin{array}{l}\text { Identification } \\
\text { methods }\end{array}$} \\
\hline & & $\begin{array}{c}\text { Control } \\
(\%)\end{array}$ & $\begin{array}{c}\text { Nano-ferric } \\
\text { oxide (50 } \\
\mathrm{mg} / \mathrm{l})(\%)\end{array}$ & $\begin{array}{c}\text { Nano-ferric } \\
\text { oxide }(100 \\
\mathrm{mg} / \mathrm{l})(\%)\end{array}$ & & \\
\hline 1 & $\alpha$-thujene & 0.11 & 0 & $0_{-}$ & 850 & MS, RI \\
\hline 2 & $\alpha$-pinene & 3.22 & 2.01 & 0 & 855 & " \\
\hline 3 & $\beta$-pinene & 1.00 & 0 & 0 & 190 & $"$ \\
\hline 4 & $\beta$-myrcene & 1.03 & 0 & 0 & 920 & $"$ \\
\hline 5 & $P$-cymene & 15.45 & 12.76 & 10.65 & 950 & $"$ \\
\hline 6 & $\beta$-phellendrene & 3.54 & 0 & 0 & 954 & $"$ \\
\hline 7 & limonene & 0.51 & 2.87 & 5.98 & 960 & $"$ \\
\hline 8 & $\gamma$-terpinene & 21.02 & 23.65 & 28.45 & 980 & $"$ \\
\hline 9 & 4-terpineol & 0 & 0.65 & 1.67 & 1.63 & $"$ \\
\hline 10 & cis limonene oxide & 1.78 & 1.98 & 2.87 & 1085 & $"$ \\
\hline 11 & Dodecane & 0 & 0.22 & 1.00 & 1110 & $"$ \\
\hline 12 & $\beta$-fenchyl alcohol & 0.76 & 0 & 0 & 1126 & $"$ \\
\hline 13 & Thymol & 18.00 & 20.12 & 32.78 & 1208 & $"$ \\
\hline 14 & Ethylene methacrylate & 0.54 & 0.49 & 0.26 & 1235 & $"$ \\
\hline 15 & Pentadecane & 0 & 0.35 & 2.11 & 1264 & $"$ \\
\hline 16 & Hexadecane & 0.11 & 0 & 0 & 1285 & $"$ \\
\hline 17 & Nonadecane & 0.02 & 0 & 0 & 1293 & $"$ \\
\hline 18 & Carvacrol & 1.43 & 5.77 & 12.00 & 1306 & $"$ \\
\hline \multicolumn{2}{|c|}{ Total } & 68.52 & 70.87 & 97.77 & & \\
\hline \multicolumn{2}{|c|}{ Yield } & 1.14 & 2.00 & 3.98 & & \\
\hline
\end{tabular}

${ }^{\mathrm{a}}$ Percentage composition determined on column HP $5^{\mathrm{b}}$ The retention Kovats indices were determined on HP 5 capillary column in reference to $n$-alkanes. MS = Mass spectroscopy, RI $=$ Retention index.

As shown in Table 2, the extraction yield of $C$. copticum ranged from lowest $90.15 \pm 14 \mathrm{mg} / \mathrm{g}$ (control) to highest $150.66 \pm 05 \mathrm{mg} / \mathrm{g}$ (nano-ferric oxide $(100 \mathrm{mg} / \mathrm{l})$. Among the three $C$. copticum extracts, C. copticum treated with nano-ferric oxide at $100 \mathrm{mg} / \mathrm{l}$ showed the highest total phenolics $(306.87 \pm 90 \mathrm{mg} / \mathrm{g})$ and highest total flavonoid content $(166.19 \pm 39 \mathrm{mg} / \mathrm{g})$. Furthermore, the total

Table 2. Effect of nano-ferric oxide on extraction yields, total phenolic contents and total flavonoid contents of C.copticum extracts.

\begin{tabular}{clccc}
\hline Extract & $\begin{array}{c}\text { Extraction } \\
\text { yield }^{\mathrm{a}}\end{array}$ & $\begin{array}{c}\text { Total } \\
\text { phenolic }^{\mathrm{b}}\end{array}$ & $\begin{array}{c}\text { Total } \\
\text { flavonoid }^{\mathrm{c}}\end{array}$ \\
\hline 1 & Control & $90.15 \pm 14$ & $160.07 \pm 45$ & $96.04 \pm 04$ \\
2 & Nano ferric oxide $(50 \mathrm{mg} / \mathrm{l})$ & $95.33 \pm 12$ & $205.87 \pm 54$ & $104.55 \pm 18$ \\
3 & Nano ferric oxide $(100 \mathrm{mg} / \mathrm{l})$ & $150.66 \pm 05$ & $306.87 \pm 90$ & $166.19 \pm 39$ \\
\hline
\end{tabular}

The data are expressed as mean $\pm \mathrm{Sd}$. ${ }^{\mathrm{a}}$ Expressed as $\mathrm{mg}$ of extract per $\mathrm{g}$ dry material. ${ }^{\mathrm{b}}$ Expressed as $\mathrm{mg}$ of gallic acid per $\mathrm{g}$ dry extract. ${ }^{\mathrm{C}}$ Expressed as $\mathrm{mg}$ of rutin per $\mathrm{g}$ dry extract.

phenolic and total flavonoid contents exhibited the descending order among: $C$. copticum extract (treated with nano-ferric oxide $100 \mathrm{mg} / \mathrm{l}$ ) > C. copticum extract (treated with nano-ferric oxide 100 
$\mathrm{mg} / \mathrm{l})>$ C. copticum extract (treated with control). These results showed that the total phenolic and total flavonoid contents have an obvious variation in various concentrations nano-ferric oxide.

Table 3. Antioxidant activity of essential oil component from $C$. copticum: scavenging activity (expressed as $\mathrm{IC}_{50}$ values: $\mu \mathrm{g} / \mathrm{ml}$ ), and $\beta$-carotene bleaching test. Reducing power was expressed as $\mathrm{EC}_{50}$ values $(\mu \mathrm{g} / \mathrm{ml})$. Butylhydroxyanisole (BHA) and ascorbic acid (AA) were used as positive controls.

\begin{tabular}{lll}
\hline \multirow{2}{*}{ Tested compounds } & Control & $\begin{array}{l}\text { Nano-ferric oxide } \\
(100 \mathrm{mg} / \mathrm{l})\end{array}$ \\
\cline { 2 - 3 } & $\mathrm{IC}_{50}(\mu \mathrm{g} / \mathrm{ml})$ & $\mathrm{IC}_{50}$ \\
\hline C. copticum essential oil & $17.09 \pm 0.03$ & $13 \pm 0.33$ \\
Limonene & $25.78 \pm 0.00$ & $22.99 \pm 0.01$ \\
$P$-cymene & $23.06 \pm 0.59$ & $20.56 \pm 0.19$ \\
$\gamma$-terpinene & $19.36 \pm 0.81$ & $16.02 \pm 0.14$ \\
Thymol & $16.59 \pm 0.05$ & $12.00 \pm 0.45$ \\
Carvacrol & $18.45 \pm 0.94$ & $14.05 \pm 0.48$ \\
C. copticum EO $\left(\beta\right.$-carotenes $\left.\mathrm{IC}_{50} \mu \mathrm{g} / \mathrm{ml}\right)$ & $16.05 \pm 0.16$ & $10.00 \pm 0.05$ \\
C. copticum EO $\left(\mathrm{PR} \mathrm{EC}_{50} \mu \mathrm{gg} / \mathrm{ml}\right)$ & $15.48 \pm 0.23$ & $10.15 \pm 0.11$ \\
BHA & $13.8 \pm 0.56$ & $13.8 \pm 0.56$ \\
AA & $10.55 \pm 0.10$ & $10.55 \pm 0.10$ \\
\hline
\end{tabular}

Values are mean $\pm \mathrm{Sd}$ of three replications. $* \mathrm{IC}_{50}$ values have been presented with their respective $95 \%$ confidence limits.

Table 4. Components identified and their antioxidant activity.

\begin{tabular}{llc}
\hline Compounds & Control $(\%)$ & Nano-ferric oxide $(100 \mathrm{mg} / \mathrm{l})$ \\
\hline Limonene & $3.21 \pm 0.77$ & $4.9 \pm 0.02$ \\
$P$-cymene & $15.55 \pm 0.04$ & $5.78 \pm 0.04$ \\
$\gamma$-terpinene & $11.45 \pm 0.34$ & $15.87 \pm 0.45$ \\
Carvacrol & $3.11 \pm 0.45$ & $15.76 \pm 0.33$ \\
Thymol & $45 \pm 0.1$ & $55.60 \pm 0.12$ \\
\hline
\end{tabular}

Results are expressed as a percentage of antioxidant activity relative. Experiments were carried out in triplicate.

The lower $\mathrm{IC}_{50}$ value indicates a stronger ability of the extract to act as a DPPH radicals scavenger while the higher $\mathrm{IC}_{50}$ value coorolate to a lower scavenging activity of the scavengers as more scavengers were required to achieve $50 \%$ scavenging reaction. The results presented in Table 3 revealed that $C$. copticum essential oil and its main constituents exhibited a remarkable activity. In particular, thymol exhibited clearly a higher activity $(12.00 \pm 0.45 \mu \mathrm{g} / \mathrm{ml})$ followed by carvacrol (14.05 $\pm 0.48 \mu \mathrm{g} / \mathrm{ml})$ and C. copticum essential oil $(13 \pm 0.33 \mu \mathrm{g} / \mathrm{ml}$, Table 3$)$, while the activities of other terpenoids were weak (limonene and p-cymene). The positive controls BHT and ascorbic acid exhibited $\mathrm{IC}_{50}$ values equal to $13.8 \pm 0.56 \mu \mathrm{g} / \mathrm{ml}$ and $10.55 \pm 0.10 \mu \mathrm{g} / \mathrm{ml}$, respectively. The monoterpene hydrocarbons, p-cymene and $\beta$-pinene were inactive (Table 3) despite previous reports of their in vitro antioxidant activities (Ruberto and Baratta 2000). Table 3 depicts the inhibition of b-carotene bleaching by the $C$. copticum essential oil.The $\mathrm{IC}_{50}$ value was $10.00 \pm 0.05 \mu \mathrm{g} / \mathrm{ml}$. As shown in Table 3, the reducing power of C. copticum, expressed as $\mathrm{CE}_{50}$, was clearly more significant than that of the positive control BHA and AA. Because of the high 
antioxidant and free radical-scavenging activities of $C$. copticum essential oil, further investigation was carried out to identify its active constituents. Therefore, a preliminary screening was initially conducted by using the dot-blot DPPH staining method on TLC. As the essential oil presented a significant antioxidant activity in the assays and bioautography test, it was subjected to the TLC for isolation of the active compounds. The major compound found in the active band was thymol $(55.60 \pm 0.12 \%$ ) (Table 4). Many aroma producer components of essential oils, such as terpenes and terpenoids, were proposed to contribute to the antioxidant activity of essential oils including thymol and eugenol, linalool and 1,8-cineole. According to these results, there is a relationship between total phenolic contents and antioxidant activity.

\section{References}

Adams RP 2001. Identification of Essential Oils Components by Gas Chromatography/Quadra pole Mass Spectroscopy. Carol Stream, IL, Allured. 61-367.

Burits M and Bucar F 2000. Antioxidant activity of Nigella sativa essential oil. Phytother Research 14: 323328.

Cuendet M, Hostettmann K and Potterat O 1997. Iridoid glucosides with free radicalm scavenging properties from Fagraea blumei. Helvetica Chimica Acta 80: 1144-1152.

European Pharmacopoeia. Vol. 3, Maisonneuve S. A., Sainte-Ruffine.1975.

Guleria S, Tiku A, Gupta S, Singh G, Koul A and Razdan V 2012. Chemical composition, antioxidant activity and inhibitory effects of essential oil of Eucalyptus teretecornis grown in north-western Himalaya against Alternaria alternata. J. Plant Biochem. Biotech. 21: 44-50.

Jimoh FO, Sofidiya MO and Afolayan AJ 2007. Antioxidant properties of the methanol extracts from the leaves of Paullinia pinnata. J. Medicinal Food 10: 707-711.

Khajeh M, Yamini Y, Sefidkon F and Bahramifar N 2004. Comparison of essential oil composition of Carum copticum obtained by supercritical carbon dioxide extraction and hydrodistillation methods. Food Chemistry 86: 587-591.

Kirby AJ and Schmidt RJ 1997. The antioxidant activity of Chinese herbs for eczema and of placebo herbs I. J. Ethnopharmacology. 56: 103-108.

Kulisic T, Radonic A, Katalinic V and Milos M 2004. Use of different methods for testing antioxidative activity of oregano essential oil. Food Chemistry. 85: 633-640.

Koleva II, Teris AB, Jozef PH, Linssen AG and Lyuba NE 2002. Screening of plant extracts for antioxidant activity: a comparative study on three testing methods. Phytochem. Analysis 13: 8-17.

Kobraee S, Shamsi K and Rasekhi B 2011. Effect of micronutrients application on yield and yield components of soybean. Ann. Biol. Res. 2(2): 476-482.

Lu CM, Zhang CYW and Tao MX 2002. Research of the effect of nanometer on germination and growth enhancement of Glycine max L. and its mechanism. Soybean Science. 21:168-172.

Oyaizu M 1986. Studies on products of the browning reaction prepared from glucose amine. Japanese J. Nutrition 44: 307-315.

Piccolella S, Fiorentino A, Pacifico S, D’Abrosca B, Uzzo P and Monaco P 2008. Antioxidant properties of sour cherries (Prunus cerasus L.): Role of colorless phytochemicals from the methanolic extract of ripe fruits. J. Agri. Food Chem. 56: 1928-1935.

Ruberto G and Baratta MT 2000. Antioxidant activity of selected essential oil components in two lipid model systems. Food Chemistry 69: 167-174.

Sheykhbaglou R, Sedghi M,Tajbakhsh Shishvan M and Seyed-Sharifi R 2010. Effect of nano iron particles on agronomic traits of soybean. Not Sciense Biological 2(2): 112-113.

Shirwaikar A, Shirwaika A, Rajendran K and Punitha ISR 2006. In vitro antioxidant studies on the benzyl tetra isoquinoline alkaloid berberine. Biological and Pharmaceutical Bulletin 29: 1906-1910. 